\title{
Students' Perception on Their English Language Learning: A Needs Analysis Study
}

\author{
${ }^{1}$ Yulia Nuzulul Hidayah, ${ }^{2}$ Dyah Setyowati Ciptaningrum \\ ${ }^{1}$ yuliafortune@yahoo.com, ${ }^{2}$ dyah.ciptaningrum@gmail.com \\ ${ }^{1,2}$ Yogyakarta State University Yogyakarta, Indonesia
}

\begin{abstract}
A needs analysis has been considered as a fundamental part of the curriculum development. Moreover, need analysis assists in identifying which aspects of students' learning that need to be improved. This paper aims to investigate the need of twenty-three first graders of one of the rural junior high schools in Gunungkidul, Yogyakarta in Academic Year 2017/ 2018. The needs analysis is implemented to provide relevant information for the teacher in designing the curriculum of the second semester. It is imperative for the school to revisit its curriculum to accommodate their students' needs since the school is located in a rural area which means that its students have different characteristics. The instruments were in the form of observation checklists, interview guidelines, and questionnaires. The findings of the study conveyed that more than $50 \%$ of the students prefer doing the task in group, some students find difficulties in learning English especially in having good pronunciation, arranging words into sentences, understanding texts, writing short texts and practicing the dialogues. Those findings would be the basis in developing the curriculum for the first graders of a senior high school in Gunungkidul in the second semester of Academic Year of 2017/2018.
\end{abstract}

Keywords: Curriculum; Need analysis; Students' Perception.

\section{Introduction}

There has been a significant change of English Language Teaching (ELT). These years, language teaching encountered innovations and changes. There were factors correlated that cause to the perspectives of English teaching from ten years ago, such as (A) Methods decline, (B) Bottom-up and top-down as commonly used approaches, (C) New innovation of English knowledge, and (D) Teaching multiple language skills in contextualized and integrated way [1]. As English is an international language and a mean of communication among people, the concern in teaching the language cannot be ignored. A tremendous concern on the content of knowledge should be taken into account since it is a skill that should be understood and practiced, not solely a lesson of school.

Student-centered and conventional curriculum own significant difference in term of the involvement of students in the classroom activities and decision making as documented by Cook [1]. He explained that in student-centered learning, students are actively participating and take a part in learning and curriculum decision making. Moreover, teachers have the responsibility to understand the students' needs before developing language teaching curriculum otherwise it may cause teaching and learning problems [3].

Therefore, it is necessary to understand the types of students' needs such as special needs, very slow, disruptive, and medium-ability students in the classroom since the school belongs to inclusive education. One of the rural junior high schools in Gunungkidul, Yogyakarta is identified as the inclusive school since the school accepts the students with special needs. One 
of the data was gotten through teacher's interview, she added that her school was located in a remote area which had a contrast characters with other general schools and belonged to the inclusive school. An inclusive school is significant in providing equal rights of gaining education for special-needs students with the normal students[4]. In short, a special curriculum on the mixed education among normal and special-needs students are provided by inclusive schools as a way to develop both students' potentials as well.

In accordance with students' different characteristics, the teachers should push themselves more seriously to control the students. Some students were not interested and lack of motivation toward the learning and instructions. Then, the teacher asked them to do a reading comprehension task. There were 20 questions for each student, and the result revealed that three students gained score 70 from 19 students. However, the other students got below score 70. Then, it was complicated to manage the class for her due to students' different characteristic and capability. Before coming to the current schools, students must have been from different schools which applied different atmosphere too in term of the English subject. Thus, students' needs and weakness of learning are examined by needs analysis as an effort to involve students in developing their potential in optimal achievement through an effecting learning content. It is significant to conduct a needs analysis in achieving relevant language teaching.

Moreover, need analysis assists in identifying which aspects of students' learning that needs to be improved. This paper aims to investigate the need of twenty-three first graders of one of the rural junior high schools in Gunungkidul, Yogyakarta in Academic Year 2017/ 2018. It is implemented to provide relevant information for the teacher in designing the curriculum of the second semester. It is imperative for the school to revisit its curriculum to accommodate their students' needs since the school is located in a rural area which means that its students have different characteristics.

\section{Literature Review}

Factors that should be considered in discovering relevant analysis on students' needs analysis are needs, potential and route constraints. Hutchinson and Waters [5] believed that if teachers, students and other officials are aware of students' reasons in learning language, the content of teaching will also be influenced, and students' potentials are able to be improved.

There are two kinds of students' needs; those are target needs defining as needs of students toward target situation and learning needs understood as needs of students toward action in learning [5] as quoted in [6]. Aspects of students' target need consist of needs, lacks and wants of students. Needs is related to students' skills which they need to understand, wants is needs which depend on students availability and the provided time, while lacks relates to students' competence before the treatment of learning using needs analysis.

Meanwhile, a study conducted by Basturkmen [7] examined the needs analysis significance for ESP and the way of teachers and the developer of course on identifying students' needs. The first point is a discussion on the importance of needs analysis. Moreover, another point reveals that a needs analysis can be used for students' learning assessment. In short, needs analysis owns a broad advantage for both students and teachers.

In addition, identifying the junior high school students' needs, Avgerou [8] deliberated questioner and discussion for 22 students in Aigio, Greece. He found that $73 \%$ would like to use authentic recordings for listening and 59\% would like to carry out a research project with the bibliography exclusively in English. A remarkable percentage of 50\% stated that they would initiate class discussions in English on issues of their choice and $45 \%$ of learners stated that they would be willing to read books in English in order to improve their reading skills 
when, at the same time, the majority of the respondents seem unwilling or unable to tackle reading texts in the school textbooks.

Collecting data in a needs analysis research done by Andi \& Arafah [9], they attached questionnaire and interview to get the data which the questioner was differentiated into five parts such as general information, problems, priorities, attitudes, and abilities. As a result, one unit of needs analysis based on instructional materials had the impact on the materials development methodology related a lesson plan and a prototype.

In the narrowest sense, needs analysis is a pre-activity before teaching students as a way to collect relevant information about students needs towards the course to be taught which will be beneficial in deciding the focus, the content of the course and teaching method. Students' needs and teachers' understanding on learning situation are developed. Therefore, Basturkmen[7] confirmed that the quality of data analysis of needs analysis is not measured by the amount of collected data but the selection of data. In teaching language, a focus that should be concerned is the type of language. The specific points are commonly described in the syllabus or lesson plan. Thus, the students will be engaged in learning activities if the syllabus contains items of learning materials correlated with students' needs[7].

\section{Methodology}

In conducting a needs analysis, this research is a part of research and development (R\&D) in designing English curriculum. The specific aspect of this research is the students' needs for English language learning in terms of learning materials and manners of learning of the first grader of the junior high school students. The various sources of collecting data used questionnaire, interview, and observation. In addition, these three data collection will be described below.

The researcher decided to use structured questionnaires as it was easier to analyze and to fill by the first grade students of junior high school. Therefore, from those criteria of writing questionnaires items, in this need analysis, the researcher will adapt questionnaire items from [10]. The researcher adapted some items from him and added some items to collect additional information from students.

Furthermore, the questionnaire was presented and answered by 22 students (11 girls and 12 boys) in the first class of Junior High School in Panggang, a rural area of Gunungkidul, Yogyakarta. Expert judgments were conducted to validate the questionnaire. In the first part, there were 5 questions. Since the first grade was the new students in that school and school indicated as an inclusive school, the researcher thus chose the class as the respondent. Also, there were only three classes in this school. In other words, each grade had only one class. The school has been represented as one of the schools located in a rural area since the school has the different characteristics with the general schools and different students' proficiency from their school before. As those reasons, the results of the questionnaire might be of a precise interest in order to redesign the existing curriculum.

The questionnaire consisted of two parts. Part one consisted of general statements about how students' point of view in English, the activity that they prefer, the way they do the exercise, the difficulties in the classroom learning and what possible facility support their learning. While in part two conveys the students' need in learning English looked for comprehensively

In addition, the researcher used a structure in-depth interview in which a particular set of predetermined questions are prepared by the interviewer. The interview questions are related with the problems and experienced teacher during the process of teaching English in the classroom supported by the way how to solve the class problems and what kinds of learning 
materials or activities mostly the students' want in learning. And the last was an observation to know the classroom characteristics and the students' behaviors in learning.

\section{Results and Discussion}

This study aims to investigate the need of twenty-two first graders of one of the rural junior high schools in Gunungkidul, Yogyakarta in Academic Year 2017/ 2018. Questionnaires were distributed to know the students' wants and their difficulties in learning English. Findings and discussion from the instruments were presented into two parts below.

\section{The result students' language learning perception}

In implementing students' needs analysis, it is also important to consider the physical classroom needs. In the first part, there were 5 questions. The first question was about students' view about English while the second question was about their perception in English classroom activities. The third one was about the students' preference on doing the task. In addition, the fourth one was about the students' difficulties in learning English and the last one was about the supporting facilities for learning. Those description will be shown in the following result below.

Statement 1: Students' view about English

According to the result, most of the students liked the English subject. The teacher should maintain students' motivation on the students' learning. Therefore, it can be one of the considerations in designing materials and syllabus.

Statement 2: Students' perception about English classroom activities

Then, all of the students enjoy the activities in teaching and learning process. Thus, the researchers should reflect what teacher has done so far in classroom activities, which can be the guidance to create more enjoyable activities that make students engage in the teaching and learning process.

Statement 3: Students' view in doing the task

From the chart above, it can be reported that more than $50 \%$ of the students prefer to do the task in the group. On the other hand, the percentage of the students who choose doing task individually and in pair is equal. In conclusion, the researchers can create more tasks and activities that can be done in groups, and also provide individual and in pair activities. Needs analysis also improves students' interpersonal skills. The skills make students capable to communicate and interact effectively with students and teachers in the classroom as a way to succeed learning goal[11]. Graves [11] emphasized that possessing interpersonal skills is important since it is the group work and cooperative learning base.

Statement 4: Students' difficulties in learning English.

The results of students' difficulties in learning English are given in Figure 1 as follow.

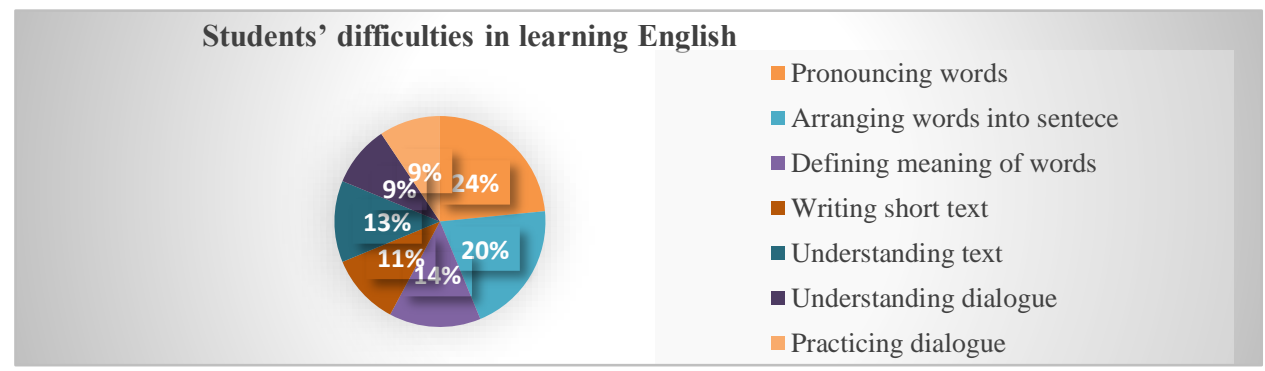

Fig 1. Students' difficulty in learning English 
The chart above shows students' difficulty in learning English which can be arranged from the most into the less; which are 1) pronouncing words $(24 \%), 2$ ) arranging words into sentence $(20 \%), 3)$ defining words (14\%), 4)understanding text (13\%), 5) writing short text $(11 \%), 6)$ practicing dialogue $(9 \%)$, and 7$)$ understanding dialogue $(9 \%)$. As consequence, the higher percentage of the students' difficulties can be given consideration in revising the curriculum content. Those are pronouncing words and arranging words into sentences, to be the focus of materials and syllabus development.

Statement 5: Supporting facilities

When a smartphone can support the learning process, it is attached on this questioner. The finding illustrated that most of the students have the smartphone. As a creative teacher or a various teaching technique given, the smartphone can be utilized the teaching and learning activities.

As an impact, an effective learning content will affect to the emergence of the target situation in the classroom that the aim of language learning as communication is successfully achieved. Hirst [12] explained that learning activities are part of students, hence it is equitable enough for the design of curriculum concept in treating students rather than the curriculum that only benefit to particular students seen through its educational objectives, and it is also able to handle the teaching current methods. The curriculum of education should provide vivid aims if plans and aims are important things in curriculum planning, thus, a relevant planning depends on how vivid the aims are.

\section{Students' need on learning}

In this part, the data would be presented in the description of analysis summarization about the students' need on their learning. There were fifteen questions attached in the second part of questioner.

Statement 1: Learning vocabularies using pictures

Based on the students' interview, they were recognized to like English, thus, they preferred to learn vocabulary using pictures. In redesign teacher's teaching, teacher may use pictures as one of the media to teach vocabulary.

Statement 2: Memorizing English vocabularies

The statement 2 told that 13 students were willing to memorize the vocabularies of English. Only three students who did not like to memorize English vocabulary while the rest of them like to memorize English vocabularies. It may indicate that the English words repetition is needed during teaching process by giving some vocabularies by drilling techniques.

Statement 3: Pronouncing English words

To encourage the students' pronunciation practice, statement 3 was deliberated to give the information about what they liked most in pronouncing some English words or vocabularies. In giving the materials, dialog or conversation may include in the learning process since only one student who does not like saying or speaking the words using English language. Additionally, drilling technique may support their ability to memorize. Then, giving some vocabularies note or the list of new or difficult words may be included in the part of making the curriculum development later. Moreover, teacher can guide the students to pronounce the words and the meaning as well.

Statement 4: Arranging words into sentences

Furthermore, responding the question number 4, the total amount of the students who like arranging the words become sentences did not show significance differently. Most of them 
were willing to arrange some words in various exercises. Thus, the teacher may give various exercises or tests in the form of arranging the words like giving the random words which need to be fulfilled by the students in the correct sentences. Or teacher may give some picture series which need to be translated by the students in the good simple sentence form in the various content of learning material.

Statement 5: Making sentences in English

Question number 5 shows that thirteen students are feeling good to make the sentence in English. However, only six students who like to make sentences and the rest of them do not like to make the sentences. To address the situation, teacher may give the freedom for the students to make the simple sentence as long as still related to the topic during teaching process at that time. In another side, teacher may give clue in the form of oral and written command to guide the students to make the sentence.

Statement 6: Writing a short text in English

Then, the answer analysis of statement number six pursued that numerous students tend to be neutral in writing a short text in English. It means that they feel not so interested in this kind of activity. Thus, in designing several fun activities and materials for writing a short text required to be highlighted.

Statement 7: Reading English text

There were no significant differences answer from students towards question number 6 and 7. 12 from 23 students felt neutral in reading text in English. On the other hand, 10 students like to do this activity. From this finding, the teacher should create more exciting ways in teaching and learning process, specifically in reading activities. In fact, this data cannot be neglected in designing the materials and syllabus.

Statement 8: Practicing dialog

The students' need in learning activities in the classroom based on the question number 7 , it can be seen that 12 students tend to like practicing the dialogue activities from the course book and the rest of them do not feel the same. In this case, developing such joyful activities of practicing dialogue from the course book is a good consideration in designing the materials then.

Statement 9: Doing conversation using English with their friends

In statement number 9, most of the students liked to have conversations with their classmates in English. Thus, it is important to make creative speaking activities such as simulation, role-play and so on. The suggestion for the teacher or curriculum developer needs to consider these kinds of activities in designing materials and syllabus to enhance students' oral performance.

Statement 10: Listening conversation from the recording

It could not be ignored that most of the students love listening to dialogues from recording. This kind of listening activity should be maintained and developed by the researchers in this project.

Statement 11: Listening English using song

The song was regarded as the most students' preferred in learning English. The data showed that almost all the students liked listening a song as one of their ways to learn English. Therefore, this kind of listening activity should be included in the syllabus and the materials in revisiting its curriculum to accommodate their students' needs.

Statement 12: Watching English movie

The data showed that 15 students liked learning by watching a movie as one of their ways to learn English. Therefore, watching a movie can be included in the curriculum development for the syllabus and the materials as one of the activities in the teaching and learning process. 
Statement 13: Learning English through the game

Based on the data above, the analysis on the statement number 13, it can be said that almost all the students like games. Thus, it is important to use games as one of the activities in the class. For instance, teachers or curriculum developers need to consider this kind of activity in designing materials and syllabus to enhance students' learning.

Statement 14: Using LCD projector while learning

Responding to that statement, 21 students prefer to be taught using LCD. During the observation, students gave more attention on teacher's teaching LCD compared to lecturing. The rest of them are neutral.

Statement 15: Using laptop or smartphone to learn in the classroom

For the last statement in the questioner, the data showed that the use of laptop and smartphone or ICT based on the teaching and learning process was interesting for the students. Most of the students like to use it during the teaching and learning process. Therefore, they can utilize technology for enhancing students' learning.

Thus, students' need analysis can be the main factor that teachers should consider in developing curriculum [10]. In addition, teachers can be argued as extremely excellent sources of needs analysis information as they commonly understand their students well including knowing students' performance in doing various tasks and the results of those tasks[6]. Needs analysis is not merely applied in narrow fields as vocational learning or ESP, it is also used for other cases of English learning and teaching as for instance in EFL learning [10].

\section{Conclusion}

Thus, the needs analysis is done to provide the relevant information for the English teacher in designing the curriculum of the second semester. It is imperative for the school to revisit its curriculum to accommodate their students' needs since the school is located in a rural area which means that its students have different characteristics. As the result, since most of the students like English subject, teacher can rearrange the activities into enjoyable and fun learning. Through questioner result, more than $50 \%$ of the students prefer to do the task in group and do the task in various exercises such as arranging the words become sentences, practicing dialogue, learning vocabulary using pictures, pronouncing some English words or vocabularies, listening a song, playing games, and even though the students sometimes get the difficulties in doing those activities. For more interesting activities, most students prefer to deliberate the media in the form of ICT such as LCD, laptop, and smartphone in the learning process. However, the highest students' difficulty in learning English is pronouncing words, then followed by arranging the words become sentences. Therefore, a syllabus framework of this needs analysis can be considered in redesigning the English learning program in one of the rural junior high school of Yogyakarta, Indonesia in academic year 2017/18.

For the suggestion, the teacher should consider all mentioned point to develop joyful activities in order to fulfill the students' need in learning English. In developing the curriculum, it is crucial to attach the communicative activities such as simulation, project, role play, and others to enlarge the students' oral performance.

We hope that the results of our finding would guide educators and other academics to examine students' specific learning in order to design the learning that meets students' needs. For further studies, it is suggested that doing more wider themes in questioner design such us focusing in assessment or evaluation, deliberating the students' background, and attaching the quantitative data forms so that the finding will impact the great result. In addition, as the researchers' recommendation, since this study only interviewed the teacher, thus, interview 
with the students can be added as enlarging the data sources in data collection in order to impact wider information as the supporting data analysis.

\section{Acknowledgment}

A great thanks to Mrs. Dyah Setyowati Ciptaningrum as my collaborator who has given me the chances and comments and helped me in writing this article.

\section{References}

[1] V. Cook, Teaching Listening and Speaking: From Theory to Practice, 4th ed., vol. 55, no. 2. London: Hodder Education, 2008.

[2] A. R. Fatihi, "The role of needs analysis in ESL program design," South Asian Lang. Rev., vol. 13, no. 1 \& 2, pp. 39-59, 2003.

[3] S. Kaur, "ESP course design: Matching learner needs to aims," English Specif. Purp., vol. 6, no. 1, 2007.

[4] G. Lindsay, "Educational psychology and the effectiveness of inclusive education/mainstreaming," Br. J. Educ. Psychol., vol. 77, no. 1, pp. 1-24, 2007.

[5] T. Hutchinson and A. Waters, "English for specific purposes: A learning-centred approach." Cambridge University Press, New York, 1948.

[6] I. S. P. Nation and J. Macalister, Language curriculum design. New York: Routledge Taylor \& Francis group, 2010.

[7] H. Basturkmen, Developing courses in English for specific purposes, 1st ed. New York: Palgrave Macmillan, 2010.

[8] E. Avgerou, "Needs analysis of the students of the 3d class of Junior High School," English Linguist. Res., vol. 5, no. 2, pp. 45-56, 2016.

[9] K. Andi and B. Arafah, "Using needs analysis to develop English teaching materials in initial speaking skills for Indonesian college students of English," Turkish Online J. Des. Art Commun., no. April, pp. 419-436, 2017.

[10] J. C. Richards, Curriculum development in language teaching, 1st ed. United States of America: Cambridge University Press, 2001.

[11] K. Graves, Designing Language Courses: A guide for teachers. Canada: Heinle \& Heinle Publishers, 2000.

[12] P. H. Hirst, Knowledge and the curriculum: a collection of philosophical papers. London \& Boston: Routledge \& Kegan Paul Ltd, 1974. 